\title{
Air and shipborne magnetic surveys of the Antarctic into the 21st century
}

\author{
A. Golynsky ${ }^{\text {a,* }}$, R. Bell ${ }^{\text {b,1 }}$, D. Blankenship ${ }^{\text {c,2 }}$, D. Damaske ${ }^{\text {d,3 }}$, F. Ferraccioli e,4, C. Finn ${ }^{\text {f,5 }}$, D. Golynsky ${ }^{\text {a,6 }}$, \\ S. Ivanov ${ }^{\text {g,7 }}$, W. Jokat ${ }^{\text {h,8 }}$, V. Masolov ${ }^{\text {g,6 }}$, S. Riedel ${ }^{\text {h, }}{ }^{\text {, R. von Frese }}{ }^{\mathrm{i}, 9}$, D. Young ${ }^{\mathrm{c}, 2}$ \\ and ADMAP Working Group
}

a VNIIOkeangeologia, 1, Angliysky Avenue, St.-Petersburg, 190121, Russia

b LDEO of Columbia University, 61, Route 9W, PO Box 1000, Palisades, NY 10964-8000, USA

c University of Texas, Institute for Geophysics, 4412 Spicewood Springs Rd., Bldg. 600, Austin, Texas 78759-4445, USA

d BGR, Stilleweg 2 D-30655, Hannover, Germany

e BAS, High Cross, Madingley Road, Cambridge, CB3 OET, UK

${ }^{f}$ USGS, Denver Federal Center, Box 25046 Denver, CO 80255, USA

g PMGE, 24, Pobeda St., Lomonosov, 189510, Russia

h AWI, Columbusstrasse, 27568, Bremerhaven, Germany

${ }^{i}$ School of Earth Sciences, The Ohio State University, 125 S. Oval Mall, Columbus, OH, 43210, USA

\section{A R T I C L E I N F O}

\section{Article history:}

Received 1 August 2011

Received in revised form 27 January 2012

Accepted 13 February 2012

Available online $\mathrm{xxxx}$

\section{Keywords:}

ADMAP

Geophysical surveys

Magnetic anomalies

Crustal studies of the Antarctic

\begin{abstract}
A B S T R A C T
The Antarctic geomagnetics' community remains very active in crustal anomaly mapping. More than 1.5 million line-km of new air- and shipborne data have been acquired over the past decade by the international community in Antarctica. These new data together with surveys that previously were not in the public domain significantly upgrade the ADMAP compilation. Aeromagnetic flights over East Antarctica have been concentrated in the Transantarctic Mountains, the Prince Charles Mountains - Lambert Glacier area, and western Dronning Maud Land (DML) Coats Land. Additionally, surveys were conducted over Lake Vostok and the western part of Marie Byrd Land by the US Support Office for Aerogeophysical Research projects and over the Amundsen Sea Embayment during the austral summer of 2004/2005 by a collaborative US/UK aerogeophysical campaign. New aeromagnetic data over the Gamburtsev Subglacial Mountains (120,000 line-km), acquired within the IPY Antarctica's Gamburtsev Province project reveal fundamental geologic features beneath the East Antarctic Ice sheet critical to understanding Precambrian continental growth processes. Roughly 100,000 line-km of magnetic data obtained within the International Collaboration for Exploration of the Cryosphere through Aerogeophysical Profiling promises to shed light on subglacial lithology and identify crustal boundaries for the central Antarctic Plate. Since the 1996/97 season, the Alfred Wegener Institute has collected 90,000 km of aeromagnetic data along a $1200 \mathrm{~km}$ long segment of the East Antarctic coast over western DML. Recent cruises by Australian, German, Japanese, Russian, British, and American researchers have contributed to long-standing studies of the Antarctic continental margin. Along the continental margin of East Antarctica west of Maud Rise to the George V Coast of Victoria Land, the Russian Polar Marine Geological Research Expedition and Geoscience Australia obtained 80,000 and 20,000 line-km, respectively, of integrated seismic, gravity and magnetic data. Additionally, US expeditions collected 128,000 line-km of shipborne magnetic data in the Ross Sea sector.
\end{abstract}

(c) 2012 Elsevier B.V. All rights reserved.
* Corresponding author. Tel.: + 7812 3123551; fax: + 78127141470.

E-mail addresses: sasha@vniio.nw.ru (A. Golynsky), robinb@ldeo.columbia.edu (R. Bell), blank@ig.utexas.edu (D. Blankenship),Detlef.Damaske@bgr.de (D. Damaske),ffe@bas.ac.uk (F. Ferraccioli), cfinn@usgs.gov (C. Finn), Dmitry.A.Golynsky@gmail.com (D. Golynsky), antarctida@peterlink.ru (S. Ivanov), jokat@awi-bremerhaven.de (W. Jokat), antarctida@peterlink.ru (V. Masolov), sven.riedel@geophysik.uni-kiel.de (S. Riedel), vonfrese@geology.ohio-state.edu (R. von Frese), Duncan@ig.utexas.edu (D. Young).

1 Tel.: +1 845365 8827; fax: +1 8453658156 .

2 Tel.: +1 512471 6156; fax: +1 5124718844 .

${ }^{3}$ Tel.: + 49511643 2692; fax: + 495116433664 .

4 Tel.: + 441223 221400; fax: +441223 362616 .

${ }^{5}$ Tel.: + 1303236 1345; fax: +1 3032361425 .

6 Tel.: + 7812 3123551; fax: + 78127141470 .

7 Tel.: + 7812 4221282; fax: + 78124231900 .

${ }^{8}$ Tel.: + 494714831 1211; fax: + 4947148311923 .

9 Tel.: +1 614292 5635; fax: +1 6142927688 .

\section{Introduction}

The geology of the ice-covered interior of the Antarctic is poorly known and inferences about its composition and history are based mostly on extrapolating scarce outcrops from the coastal regions towards the interior of the continent. The composite tectonic evolution of the continent beneath the Antarctic Ice Sheet involves great uncertainties due to the paucity of outcrops and geochronology data. However, aeromagnetic data can help constrain the interpretation of basement features and expand our geological knowledge of Antarctica. Anomalies arising from the magnetic character of rocks in the earth's crust have revealed many aspects of earth processes and 
geodynamics, and mapping them comprehensively has been a focus of many Antarctic expeditions for more than fifty years.

The first magnetic anomaly map for the Antarctic region south of $60^{\circ} \mathrm{S}$ combined over 1.5 million line-km of marine and aeromagnetic survey data collected by the international community from the IGY 1957-58 to 1999 (Golynsky et al., 2001, 2006a) and more than 5.8 million line-km of the satellite (Magsat) observations. It provides a unique window on basement geology, structural architecture and tectonic evolution of the Antarctic crust and the $5-\mathrm{km}$ grid of the ADMAP map is available at www.geology.ohio-state.edu/geophys/ admap. The CD of the survey data in the compilation was released to the World Data Centers in 2008 and incorporated into the World Digital Magnetic Anomaly Map and EMAG2 of NOAA (e.g. Maus et al., 2009).

The line coverage of marine and airborne surveys in the first ADMAP compilation is shown in Fig. 1, where large regional gaps in coverage are evident especially for the East Antarctic. Particularly large gaps are between the mountainous regions of Dronning Maud Land and the South Pole, As well as between Wilkes Land and Adélie Land. Very sparse coverage in Queen Mary Land and adjacent areas includes several historical reconnaissance profiles flown in the late 1950s, local narrow surveys along the coastal region and small surveys over the Antarctic oases such as Bunger Hills and the Windmill Islands. The Ross Ice Shelf area also was visited by only several profiles that were gathered in early 1960s, even though geophysical information from this region would contribute greatly to better understanding the West Antarctic Rift system that was mapped largely by seismic data over the Ross Sea shelf (Behrendt et al., 1991; Brancolini et al., 1991; Cooper and Davey, 1987; Hinz and Block, 1984; Hinz and Kristoffersen, 1987; Zayatz et al., 1990).

The most poorly mapped offshore region includes the Amundsen Sea sector and eastern part of the Ross Sea, where the data were mostly obtained from random tracks with orientations that are rarely optimum for investigating the magnetic fabrics. The eastern Weddell Sea and western Riiser-Larsen Sea require additional surveys to better constrain the break-up of Antarctica and Africa and determine the spatial extent of the Maud Rise submarine igneous province.

To help fill in the coverage gaps between the near-surface surveys, the satellite magnetic observations at roughly $400-\mathrm{km}$ altitude from the 6-month Magsat mission were used. However, these satellite data were collected during austral summer and fall periods, and thus are maximally corrupted by external magnetic field variations. Much cleaner Antarctic satellite magnetic observations from several austral winters are now available from the Ørsted and CHAMP missions at altitudes of about 600 and $400 \mathrm{~km}$, respectively (Kim et al., 2004 , 2007). The measurement accuracies of these observations are also better than Magsat's by roughly an order of magnitude.

Effective estimates of near-surface anomalies in the coverage gaps can be obtained by optimized the inversion of the satellite data to match the near-surface anomaly observations around the gap's perimeter (Kim et al., 2004, 2007). Simulations found that the newer satellite data improve gap estimates by nearly $75 \%$ relative to the Magsat nearsurface anomaly predictions. Limited testing with data from new surveys conducted since 1999 shows that the gap predictions from

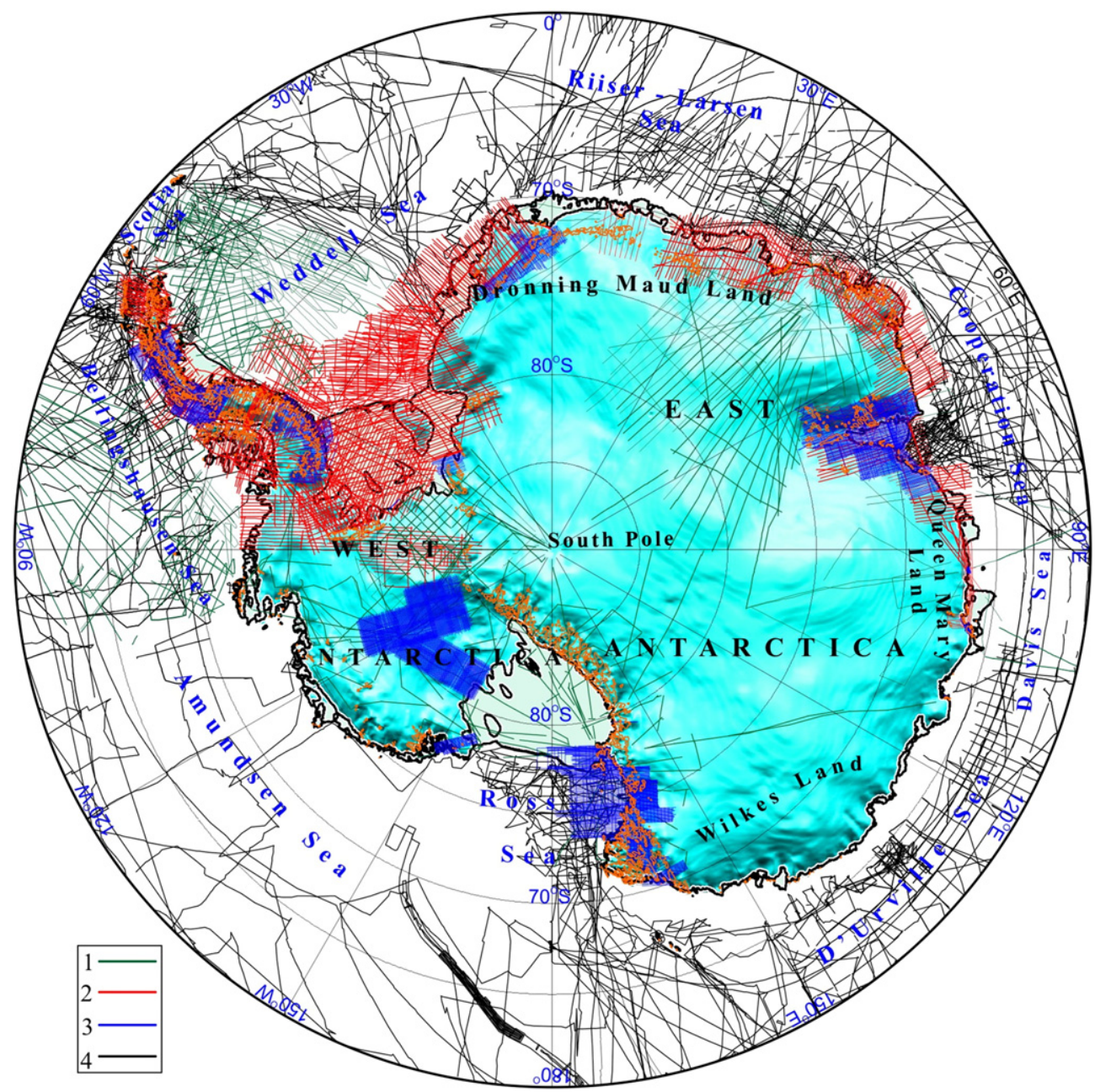

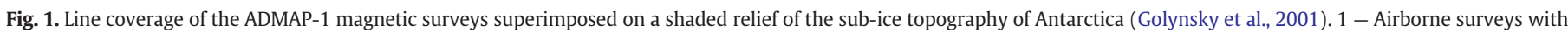
flight-line spacing $\sim 50 \mathrm{~km} ; 2$ - airborne surveys with flight-line spacing $\sim 20 \mathrm{~km} ; 3$ - airborne surveys with flight-line spacing $\sim 5 \mathrm{~km}$; 4 - shipborne surveys. 
the Ørsted and CHAMP and near-surface observations are regionally consistent (Kim et al., 2007). In view of these results, the Magsatbased gap predictions in the initial ADMAP compilation have been replaced by Ørsted- and CHAMP-based predictions (von Frese et al., 2008).

Further enhancement of the longer wavelength features of the ADMAP compilation can result from the lower altitude $(\sim 330 \mathrm{~km})$ observations obtained at the end of the CHAMP mission. These data can be processed into an important new boundary condition on the Antarctic crustal magnetic anomaly field (e.g., Kim et al., 2004, 2007; von Frese et al., 2005). Additional improvement of the satellitealtitude Antarctic crustal anomaly estimates will result from ESA's low-Earth-orbiting SWARM mission that is scheduled for launch in 2012. SWARM will include two satellites orbiting in tandem to map the horizontal gradients of the geomagnetic field with minimal effects from the strong, transient south polar external fields. Thus, SWARM will enable us to estimate the regional crustal anomaly field of the Antarctic with minimal ambiguity.

The ADMAP working group has also updated the database for East Antarctica and surrounding regions (Golynsky et al., 2007). To improve the magnetic anomaly pattern over this region substantially, more than 500,000 line-km of new airborne and shipborne data acquired by the international community were added to the ADMAP compilation (Anderson et al., 2006; Damaske, 1999; Damaske and McLean, 2005; Damaske et al., 2002, 2003; Ferraccioli et al., 2003 , 2005a,2005b; Ferris et al., 1998, 2002; Gandyukhin et al., 2006; Golynsky et al., 2006a, 2006b, 2006c; Jokat et al., 2003; Luyendyk et al., 2003; Shepherd et al., 2006; Stagg et al., 2004; Studinger et al., 2003, 2004, 2006).

The Antarctic geomagnetics' community remains very active in crustal anomaly mapping. Fig. 2 shows the track line coverage from the roughly 1.5 million line-km of new near-surface survey data that have been collected since 2000 and partly were not available previously. A number of the new surveys were completed as part of the International Polar Year (IPY) 2007-09 project. Incorporating the new data essentially doubles the ADMAP database and calls for the development of the next generation Antarctic map with the nearsurface magnetic survey coverage shown in Fig. 3. The new compilation also can take advantage of enhanced procedures for using stateof-the-art satellite magnetic observations to estimate near-surface anomaly values in the coverage gaps of the airborne and marine surveys. In addition, an improved core field model for the Antarctic has been developed to enhance the reduction of survey observations for their crustal anomaly components (Gaya-Piqué et al., 2006). The production of a high-degree spherical cap harmonic model of the database also has significant potential for expanding the geological utility of the ADMAP compilation (e.g., von Frese et al., 2008). The remaining sections of this paper outline the attributes and significance of the airborne and marine magnetic surveys that are available for the production of the next generation ADMAP compilation.

\section{New aeromagnetic surveys}

A number of airborne surveys carried out in the late 1990s, which were not included in the initial ADMAP compilation (Golynsky et al., 2001), are now available. They include the surveys flown over Dronning Maud Land and Cost Land by Germany's Alfred Wegener Institute (AWI) and the Federal Institute for Geosciences and Natural Resources (BGR).

The regional helicopter-borne GEOMAUD survey was flown in central DML during the austral summer season of 1995/96 with a $4.4 \mathrm{~km}$ line spacing (Damaske, 1999). The survey was flown at constant altitudes of $570 \mathrm{~m}$ over coastal areas and at $2845 \mathrm{~m}$ in the mountains. The observed pattern of magnetic anomalies over central DML mostly reflects the heterogeneous distribution of high-grade metamorphic rocks and various intrusions. However, in the central
DML many geological and geophysical aspects of the crust remain unestablished.

The AWI collected a large aeromagnetic dataset as part of the East Antarctic Margin Aeromagnetic and Gravity Experiment (EMAGE) along a $1200 \mathrm{~km}$ long segment of the East Antarctic coast over western and central DML (Jokat et al., 2003). The aircraft flight pattern between $18^{\circ} \mathrm{W}$ and $8^{\circ} \mathrm{E}$ was extended by two helicopter surveys $(\sim 20,000 \mathrm{~km})$ during the 1999/2000 season over largely unexplored regions of the western part of the Weddell Sea and in the RiiserLarsen Sea. With respect to the earlier aeromagnetic investigations in DML, up to $65 \%$ of the magnetic data, covers unexplored regions and therefore contributes a large amount of new data to the Antarctic geological research.

The EMAGE aeromagnetic data collected by the AWI along the eastern Weddell Sea and Riiser-Larsen Sea continental margins allowed Jokat et al. (2003) to establish a refined model for the timing and geometry of the early Gondwana break-up. In the Riiser-Larsen Sea/Mozambique Basin, the first oceanic crust between Africa and Antarctica formed around 155 Ma. At chron M14N, South America and Africa finally split off the Antarctic continent.

The British Antarctic Survey (BAS) collected the aeromagnetic data over Ellsworth Land in the 1997/98, the Pensacola Mountains in 1998/99, James Ross Island in 1998/99, and the western part of the Weddell Sea and coastal regions of the Antarctic Peninsula as part of the so-called Black Coast survey in 1996/97 (e. g. Ferris et al., $1998,2002)$. In total, more than 34,000 line-km of magnetic data were acquired to study structural relationship between West Antarctic crustal blocks (Antarctic Peninsula, Ellsworth-Whitmore Mountains, Haag Nunataks and Weddell Sea Embayment), the continuity of geological structure between the eastern Antarctic Peninsula and the attenuated continental crust of the Filchner Block, the presence of a dike swarm that may have fed the Dufek and Forrestal intrusions, and the volcanoes that constrain the magmatic and tectonic processes of the Antarctic plate.

The GITARA VI aeromagnetic survey in 1999/2000 field season along the Victoria Land coastal regions ( $1000 \mathrm{~km}$ corridor) between Yule Bay and Mertz Glacier was a collaboration of the BGR and Genova University (Italy) within the joint German-Italian GANOVEX VIII-ITALIANTARTIDE XV Antarctic campaign (Damaske et al., 2003). The objective was to provide a new window on the crustal structure and tectonics of the northernmost Transantarctic Mountains and its "backside" component, which is still largely unexplored. The helicopter-borne survey was accomplished with a standard profile spacing of $4.4 \mathrm{~km}$ and tieline spacing of $22 \mathrm{~km}$. Altogether 19,000 km of high-quality line data were collected over an area of $83,800 \mathrm{~km}^{2}$.

The results obtained new insight into the Transantarctic Mountains and the previously unexplored northernmost edge of Wilkes Subglacial Basin. The new aeromagnetic anomaly map revealed anomalies associated with Granite Harbour Intrusives and mafic/ultramafic rocks related with a major, but almost entirely buried fault zone of the Wilson Terrane. The anomalies in the Mawson Peninsula/Scar Bluffs region may reflect thicker mafic Jurassic intrusions or possibly Kirkpatrick basalts.

US scientists collected aeromagnetic data over western Marie Byrd Land (WMB) (Luyendyk et al., 2003) and along a transect crossing the Transantarctic Mountains in vicinity of the South Pole called the Pensacola-Pole transect (PPT) (Studinger et al., 2006). Airborne gravity, magnetic, and ice-penetrating radar data were collected in both regions by the US National Science Foundation's Support Office for Aerogeophysical Research (SOAR) during the 1998/1999 field season. The WMB survey area extended NE-SW some $470 \mathrm{~km}$ by $350 \mathrm{~km}$ and included most of the Edward VII Peninsula and all of the Ford Ranges. Flight-line spacing over most of the area was 5.3 or $10.6 \mathrm{~km}$. The PPT acquired more than 13,000 line-km of aerogeophysical data. It was flown on a grid of 11 flight lines spaced $10 \mathrm{~km}$ apart with a total of 28 tie-lines spaced $30 \mathrm{~km}$ apart. 


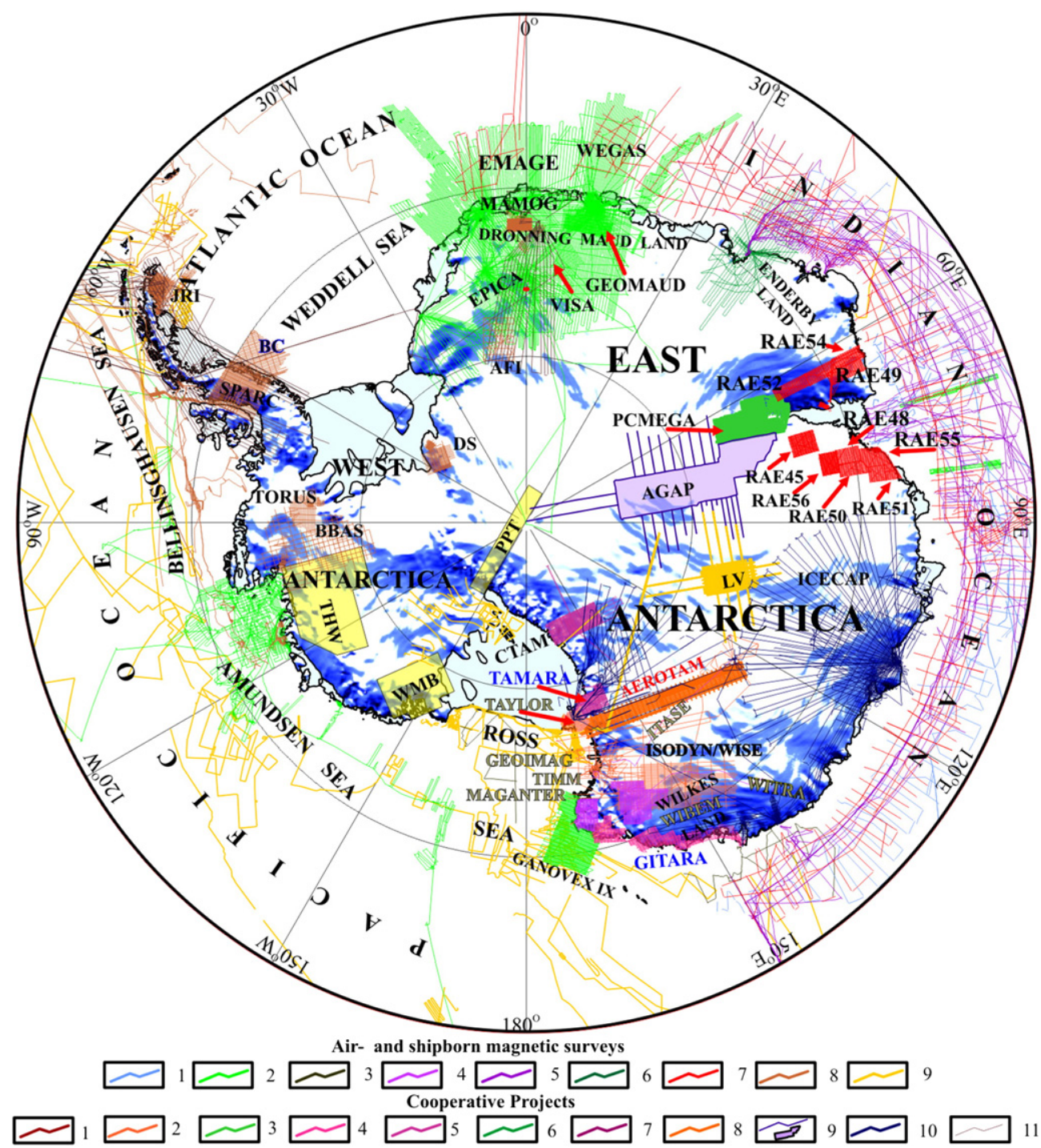

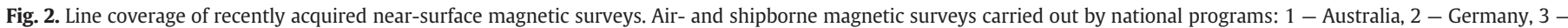

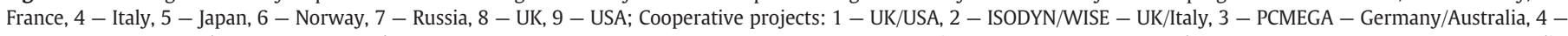

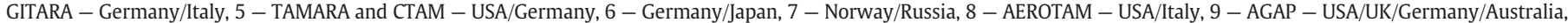
10 - ICECAP - USA/UK/Australia, 11 - DTU, NGA, University of Texas, University of Bergen/NPI/Norway, IAA/Argentina and BAS/UK.

The WMB survey area was located at the boundary between the West Antarctic Rift system and Mesozoic/Paleozoic structures developed in Marie Byrd Land. This survey was focused on determining geophysical features and structures that record the middle and Late Cretaceous development of the Ross Sea rift (Luyendyk et al., 2003). The aeromagnetic transect over the exposed Transantarctic Mountains (TAM) and the interior of the ice-covered East Antarctic shield provides for better understanding of the shield margin and its relation to younger tectonic events (Studinger et al., 2006).

The Transantarctic Mountain Aerogeophysical Research Activities (TAMARA) program of the BGR and USGS collected aeromagnetic data during the 1997/98 field season around the Royal Society Range where the West Antarctic rift system is offset along a transverse accommodation zone (Damaske et al., 2002). The collaborative efforts collected $\sim 14,100$ line-km of helicopter magnetic data over an area of about $30,000 \mathrm{~km}^{2}$. These data were integrated with other geologic and geophysical information that allowed to help resolve large scale structures along the TAM and the relationships between the longitudinal and transverse structures along the rift flank.

The AEROTAM transect was a joint US and Italian effort completed during the austral 1999/2000 summer (Studinger et al., 2004). The survey area covered an area of $1150 \mathrm{~km}$ by $116 \mathrm{~km}$ ranging from McMurdo Sound towards Dome C. The survey was flown with flight lines spaced $10.6 \mathrm{~km}$ apart and tie-lines every $31.8 \mathrm{~km}$. Additional profiles were obtained for the southern half of the Dome $C$ region with a 5.3-km line spacing. In total, more than 21,000 line-km of magnetic, gravity and radio echo-sounding data were acquired. These data outline the boundaries of several geologic and tectonic segments within the survey area. The magnetic anomaly pattern and mesa topography suggests the subglacial extent of the TAM some 400-500 km inland from the flanking rock outcrops (Studinger et al., 2004).

All acquired Antarctic surveys mentioned above are in the public domain as profiles or in gridded form. They were used to compile the new map of East Antarctica and surrounding regions (Golynsky et al., 2007). This new map displays many previously unknown magnetic patterns, lineaments and trends, and defines the spatial extent of Ferrar volcanics and plutonic Granite Harbour Intrusives in the Transantarctic Mountains as well as previously unknown tectonic trends of the East Antarctic craton. The regional aeromagnetic investigations have successfully delineated Early Paleozoic crustal features along the flanks of the West Antarctic Rift System. 


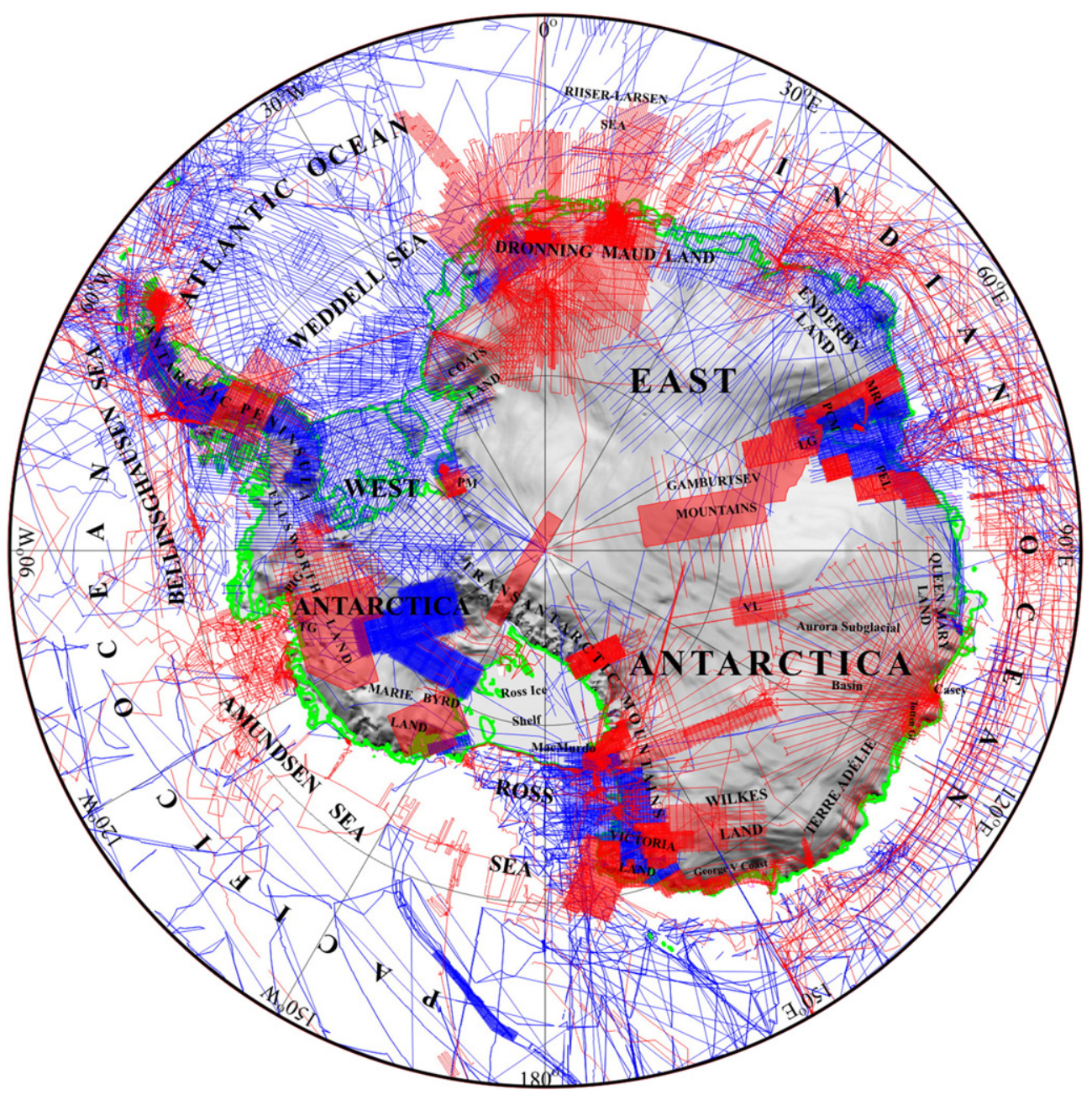

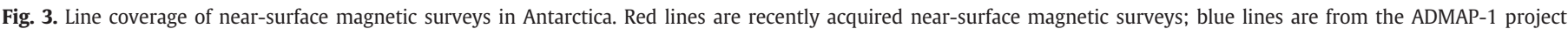

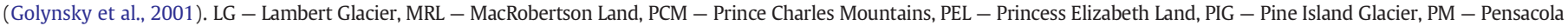
Mountains, TG - Thwaites Glacier, VL - Vostok Lake. (For interpretation of the references to colour in this figure legend, the reader is referred to the web of this article.)

Since 2000, numerous international programs have focused on the first-order geophysical mapping of tectonic and geologic structures in the interior of Antarctica and along its continental margins. Aeromagnetic flights over East Antarctica have been concentrated in the Transantarctic Mountains, over Lake Vostok, the central Antarctic Plate, the Prince Charles Mountains - Lambert Glacier area, and Dronning Maud Land - Coats Land regions (Anderson et al., 2006; Damaske and McLean, 2005; Damaske et al., 2007, 2009; Ferraccioli et al., 2003, 2005a, 2009a, 2009b; Golynsky et al., 2006a, 2006b, 2006c, 2010; Holt et al., 2010; Jokat et al., 2010; Riedel and Jokat, 2007; Shepherd et al., 2006; Studinger et al., 2003; Wilson et al., 2007; Young et al., 2010).

In West Antarctica aeromagnetic surveys were carried out over the Antarctic Peninsula, Ellsworth Land (Ferraccioli et al., 2004; 2006; Jones et al., 2003) and the Amundsen Sea Embayment during the austral summer of $2004 / 05$ by a collaborative US/UK aerogeophysical campaign (Holt et al., 2006). The majority of projects succeeded in simultaneously operating and integrating laser altimetry, ice-penetrating radar, gravimeters, and magnetometers aboard rotary and fixed-wing survey aircraft.

The US SOAR program acquired more than 20,000 line-km of aerogeophysical data over Lake Vostok during the 2000/01 season (Studinger et al., 2003). The main grid covered a 157.5 by $330 \mathrm{~km}$ area with an additional 12 regional lines extending between 180 and $440 \mathrm{~km}$ outside of the main grid. Within the main grid, flight lines were oriented E-W and spaced $7.5 \mathrm{~km}$ apart with $\mathrm{N}-\mathrm{S}$ tie-lines spaced 11.25 and $22.5 \mathrm{~km}$ apart. Flight elevations for the main grid were $3960 \mathrm{~m}$ above sea level (asl) and between $3840 \mathrm{~m}$ and 4210 masl for the regional lines. These data show that Lake Vostok is located along a major geological boundary that may be considered as a Proterozoic collision zone. Magnetic and gravity data are distinct east and west of the lake, as is the roughness of the subglacial topography (Studinger et al., 2003).

During the 2001/02 Antarctic field season, the British Antarctic Survey accomplished two aeromagnetic surveys in western Dronning Maud Land (WDML) and Coast Land (Ferraccioli et al., 2005a; Shepherd et al., 2006). Additional aerogeophysical survey was flown on a $10 \mathrm{~km}$ line spacing grid over the drainage basin of the Rutford Ice stream (West Antarctica), as part of the TORUS (Targeting ice stream Onset Regions and Under-ice Systems) project (Ferraccioli et al., 2004). New aerogeophysical maps at the edge of the Ellsworth Mountains revealed that ice streams occur in regions of complex subglacial geology where narrow rifts are not readily identified (Jones et al., 2003).

The high-resolution aeromagnetic survey over the Jutulstraumen ice stream in WDML acquired 15,500 line-km of aeromagnetic data and was flown along a 1-km line spacing grid with tie-lines $8 \mathrm{~km}$ apart (Ferraccioli et al., 2005a). This survey was part of the British Antarctic Survey's MAMOG (Magmatism As a Monitor Of Gondwana break-up) project, which included new geochemical, structural geology, geochronology, and geophysical studies over WDML. By providing new constraints on the magmatic and structural context of the 
Dronning Maud Land margin, this multidisciplinary project aimed to re-address the mantle processes responsible for the generation of the Karoo Large Igneous Province, and the initial break-up of Gondwana. New bedrock elevation, free-air and Bouguer gravity, and aeromagnetic anomaly maps were compiled. Three-dimensional modelling of the new aerogravity data indicated thinned crust beneath the northern part of the Jutulstraumen rift. Analysis of the coincident aeromagnetic data revealed that the glaciated rift is largely amagmatic and includes several narrow basins and horsts (Ferraccioli et al., 2005b).

Aeromagnetic surveying in the region of Slessor Glacier over Coats Land, which drains into the Filchner Ice Shelf, acquired 5000 line-km of data (Shepherd et al., 2006). New airborne radio echo-sounding and aeromagnetic data have been combined to infer the subglacial geology and its relation to ice flow for a region covering the three tributaries of Slessor Glacier, which is a major East Antarctic outlet glacier.

Airborne geophysical surveying over Palmer Land was flown in the 2002/03 field season as part of the SPARC (Superterranes in the Pacific margin Arc) project, gathered approximately 20,000 line-km of aeromagnetic data (Ferraccioli et al., 2006). The survey was flown with flight lines spaced $5-10 \mathrm{~km}$ apart. New airborne geophysical data revealed subglacial imprints of crustal growth of the Antarctic Peninsula by Mesozoic arc magmatism and terrane accretion along the paleo-Pacific margin of Gondwana. Potential field signatures indicated that the Antarctic Peninsula batholith is a composite magmatic arc terrane comprising two distinct arcs separated by a $>1500-\mathrm{km}$ long suture zone. Aeromagnetic, aerogravity and geological data suggested that an Early Cretaceous mafic western arc was juxtaposed against a more felsic eastern arc that, in mid-Cretaceous times, was intruded by highly magnetic tonalitic/granodioritic plutons of island arc affinity. Suturing of the two arcs against the Gondwana margin caused the mid-Cretaceous Palmer Land orogenic event. The SPARC survey results showed the utility of aerogeophysics for Mesozoic terrane studies in Antarctica, which had been recognized previously in investigations of Paleozoic (Ferraccioli et al., 2002; Finn et al., 1999) and Precambrian terranes (Golynsky and Jacobs, 2001; Golynsky et al., 2000, 2002).

Extensive airborne surveys over western and central DML were carried out in 2001/05 when the AWI together with the Technical University Dresden conducted the long-term collaborative VISA (Validation, densification and Interpretation of Satellite data for the determination of magnetic field, gravity field, ice mass balance and structure of the earth crust in Antarctica) project. VISA is focused on a number of multidisciplinary targets for studying the major structures of the East Antarctic Shield and its continental margin to achieve better understanding of Gondwana geology (Riedel and Jokat, 2007). The VISA project covered more than 1.2 million $\mathrm{km}^{2}$ from $14^{\circ} \mathrm{W}$ to $20^{\circ} \mathrm{E}$ and from $70^{\circ} \mathrm{S}$ to $78.5^{\circ} \mathrm{S}$ and filled in the biggest data gap over DML. The VISA project is continueing over the DML's onshore and offshore areas as the WEGAS (West-East Gondwana Amalgamation and its Separation) project (pers. comm. D. Steinhage, 2010) project where to date more than 53,000 (Leinweber and Jokat, 2012) line-km have been collected. During the four previous Antarctic field seasons, roughly 86,200 line-km of aerogeophysical data were obtained with an average line spacing of about $10 \mathrm{~km}$. In concert with one of the aims of the VISA project, the new datasets will contribute to validating new gravity data from the CHAMP, GRACE and GOCE satellite missions.

Off eastern Dronning Maud Land, the AWI/NIPR (NIPR - National Institute of Polar Research, Japan) aerogeophysical survey was conducted in 2006 to enhance understanding of the continental break-up between East India and Antarctica (Jokat et al., 2010). The flight altitude varied offshore between $150 \mathrm{~m}$ and $250 \mathrm{~m}$ asl and between $3000 \mathrm{~m}$ and $3600 \mathrm{~m}$ above the land surface. With the line spacing of $20 \mathrm{~km}$, more than 22,800 line-km of new aeromagnetic data were acquired.
Over the East Antarctic continental margin in the Cooperation Sea and the southern part of the Kerguelen Plateau, two narrow swath helicopter-borne magnetic surveys were acquired during austral season of 2007 in a cooperative project between AWI and VNIIOkeangeologia's 52th Russian Antarctic Expedition of Polar Marine Geosurvey Expedition (PMGE). This project was implemented in the IPY 2007/08 framework of the Plate Tectonics and Polar Gateways in Earth History project (Gohl et al., 2007a; Leitchenkov et al., 2010).

During the 2002/03 austral summer, the Prince Charles Mountains Expedition of Germany and Australia (PCMEGA) aerogeophysical survey was flown to investigate the Southern Prince Charles Mountains (SPCM) and the northern part of the subglacial Gamburtsev Mountains (Damaske and McLean, 2005). The objective was to extend the magnetic data to the south and also acquire ice-penetrating radar and gravity data to assist in understanding the Lambert rift system. Logistical reasons required the mapping of two separate regions. The main area consisted of a regular grid and the ferry area, which was flown in transit to and from the main grid and Mt. Cresswell. The main grid extended over $350 \mathrm{~km}$ from the southernmost PCM outcrops. A total of $20,515 \mathrm{~km}$ of survey lines at a $5 \mathrm{~km}$ line spacing and a $25 \mathrm{~km}$ tie-line spacing was acquired over an area of approximately $81,000 \mathrm{~km}^{2}$. An additional $9150 \mathrm{~km}$ were flown over an area of $20,000 \mathrm{~km}^{2}$ in transit from Mt. Cresswell to the main grid.

Interpretation of the PCMEGA aeromagnetic data distinguished major geological blocks (the Mawson, and Gamburtsev domains) and magnetic trends that can be correlated with the known geology of the SPCM (McLean et al., 2009). The discovered tectonic domains are supported by surface observations of rock outcrops, isotopic data, and structural mapping.

Collaborative efforts between the BGR and USGS collected data over the central TAM (CTAM) in 2003/04 field season when more than 32,000 line-km of total-field magnetic data were flown, covering an area of nearly $60,000 \mathrm{~km}$ at an average altitude of $600 \mathrm{~m}$ above the ice (Anderson et al., 2006; http://pubs.usgs.gov/of/2006/1255). The E-W lines were flown with a line spacing of $2.5 \mathrm{~km}$ over most areas and at $1.25 \mathrm{~km}$ over exposed basement rocks in the Miller and Geologists ranges with $\mathrm{N}-\mathrm{S}$ tie-lines at $25 \mathrm{~km}$ intervals. Analysis of the new magnetic anomaly data together with geology information from the CTAM showed that the East Antarctic shield in this region comprises an Archean craton modified both by Proterozoic magmatism and early Paleozoic orogenic basement reactivation (Goodge and Finn, 2010).

A collaborative aerogeophysical campaign was flown during the 2004/05 austral summer by the University of Texas' Institute for Geophysics (UTIG) and the BAS over the entire Amundsen Sea embayment (Holt et al., 2006; Vaughan et al., 2006), where the Pine Island Glacier (PIG), Thwaites Glacier, and other glaciers appear to be melting and retreating rapidly (Rignot et al., 2004; Thomas et al., 2004). This US/UK field campaign undertook a systematic geophysical survey of the entire Amundsen Sea embayment using comparable airborne survey systems. The measurements included surface elevations, ice thicknesses and subglacial bed elevations, and gravity and magnetic anomalies. The UTIG data were acquired on a $15 \mathrm{~km}$ by $15 \mathrm{~km}$ grid over the Thwaites, Smith, Kohler, Pope, and Haynes Glacier catchments and augmented by seven along-flow profiles of the major trunks and tributaries (Holt et al., 2007). Over 43,500 line-km of geophysical data were collected by the UTIG survey. Due to the need for minimal altitude changes which can disrupt airborne gravity measurements, the Thwaites survey area was subdivided into blocks of constant elevation. Typical survey clearance was $500 \mathrm{~m}$ above the surface.

A BAS Twin Otter aircraft was used to explore mainly the PIG catchment, and collected 32,000 line-km of new data (Ferraccioli et al., 2007). Most flights were in a regular $30-\mathrm{km}$ grid flown at the constant elevation (i.e., $1400 \mathrm{~m}, 1900 \mathrm{~m}$ and $2400 \mathrm{~m}$ ) required for the acquisition of gravity data. The relatively wide line spacing reflected a compromise to survey a large enough area to be significant for ice sheet models addressing the stability of this dynamic part of the West Antarctic Ice 
Sheet (Vaughan et al., 2006). This is a coarse grid for aeromagnetic surveying, but a similar BAS survey over Coats Land delineated regional subglacial geology using aeromagnetic profile data analysis (Bamber et al., 2006; Shepherd et al., 2006). Five flights were flown in draped mode with a line spacing of 3-9 km over the PIG trunk and its tributaries, thereby providing a more detailed window on subglacial topography and geology for this key feature. New UK/US aerogeophysical data will significantly enhance our knowledge of the earth's largest glaciated continental rift system, the West Antarctic Rift System and its boundaries to the adjacent crustal blocks of West Antarctica.

The Amundsen Sea embayment offshore regions were studied by the helicopters of the AWI's Polarstern during two seasons in 2006 and 2010 when more than 36,000 line-km of aeromagnetic data were acquired (e.g. Gohl et al., 2007b). New seismic, magnetic and gravity surveying of the Amundsen Sea embayment and the Pine Island Bay revealed important phases of the tectonic evolution in this area. Dominant NE-SW trending magnetic and gravity anomalies and the thinned crust indicate a former rift zone proposed to be active during or prior to the break-up between Chatham Rise and West Antarctica before or at about $90 \mathrm{Ma}$ (Gohl et al., 2007b).

An extensive aerogeophysical survey was flown over the Victoria Land during the 2005/06 Antarctic field campaign as part of the collaborative UK-Italian (ISODYN|WISE - Icehouse Earth: Stability Or DYNamism?; WIlkes Basin/Transantarctic Mountains System Exploration) project. The survey covered part of the Wilkes Subglacial Basin (WSB) and several tectonic blocks over the adjacent TAM and the Dome $C$ region and also extended to the western Ross Sea Rift. Approximately 60,000 line-km of new data were collected over an area of 767,300 $\mathrm{km}^{2}$ (Ferraccioli et al., 2009a). The main aeromagnetic grid across the WSB was flown with a line spacing of $8.8 \mathrm{~km}$, a tie-line interval of $44 \mathrm{~km}$, and at a constant nominal elevation of 2,400 m. In the western part of the survey grid, the line spacing was in part wider (i.e., $26.4 \mathrm{~km}$ ).

Aeromagnetic data have been used to investigate the subglacial geology and tectonic origin of the WSB and its three sub-basins imaged by radio echo-sounding data. Outstanding aeromagnetic lineaments on both flanks of the WSB suggest that the basin is structurally controlled (Ferraccioli et al., 2009a). New aerogeophysical data suggested that the basin contains a former broad back-arc basin and fold-and-thrust belts, forming the transition between a Precambrian craton and the Ross Orogen. The western margin of the WSB is located along the southern extension of the Precambrian-age Mertz Shear Zone and marks the edge of the Terre Adélie craton. High-frequency aeromagnetic anomalies over the WSB reveal the subglacial extent of Jurassic rocks of the Ferrar Group intruded into Beacon sediments.

Within the GANOVEX IX 2005/06 framework, an aeromagnetic survey was flown to relate tectonic structures in onshore Northern Victoria Land with offshore tectonic elements of similar age (Damaske et al., 2007). A total of 25,665 line-km were flown along a 5-km line spacing grid with tie-lines $25 \mathrm{~km}$ apart covering an area of approximately $100,000 \mathrm{~km}^{2}$. The survey covered the offshore regions along the Pennell coast between Yule Bay and Cape Adare and the Adare Trough and its possible connection with the Northern Basin in the Ross Sea. The high-resolution survey clearly showed that the Hallett volcanics of the Adare Peninsula extend north into the continental shelf beyond Cape Adare, which is of major importance for understanding the tectonic development of the Ross Sea embayment and its relation to the opening of the Tasman Gateway between Antarctica and Australia. The Adare Trough spreading anomalies and internal structuring were identified, however, uncertainty remains concerning the bending of these spreading anomalies into the Northern Basin of the Ross Sea.

The enigmatic Gamburtsev Subglacial Mountains (GSM) in the interior of East Antarctica are critical for understanding the tectonic setting and development of the East Antarctic Shield. As part of the IPY $2007 / 09$, they were studied in the 2008-09 field season by the team of scientists from 7 nations using instrumented aircraft provided by the US Antarctic Program and another from the BAS (Damaske et al., 2009; Ferraccioli et al., 2009b; Studinger et al., 2009). As a result, more than $120,000 \mathrm{~km}$ of new airborne radar, aerogravity and aeromagnetic data were acquired from two remote field camps flanking Dome A. The Antarctica's Gamburtsev Province (AGAP) project survey area covered approximately 2 million $\mathrm{km}^{2}$ of the ice sheet. The AGAP survey was flown with flight lines spaced $5 \mathrm{~km}$ apart and tielines every $33 \mathrm{~km}$ that was a compromise between the need for a smaller separation for mapping the polar diurnal variations and the operational logistics. In addition to the main survey grid, single lines spaced about $66 \mathrm{~km}$ apart were flown to connect to regional features and earlier reconnaissance surveys. The surveys are targeted at understanding the tectonic origin of these enigmatic mountains, and to provide crucial new inputs into ice sheet and climate models, and key site survey support for the ice and bedrock drilling efforts.

The new aeromagnetic data over the Gamburtsev Subglacial Mountains, combined with previous surveys, revealed fundamental geologic features beneath the East Antarctic Ice sheet critical to understanding Precambrian continental growth processes (Finn et al., 2009). Linear magnetic anomalies in the Prince Charles Mountains region apparently related to $\sim 1 \mathrm{Ga}$ orthogneiss and charnockite extend to the Gamburtsev Subglacial Mountains over a distance $>1000 \mathrm{~km}$, suggesting that these two areas may have been adjacent to each other by $\sim 1 \mathrm{Ga}$. Despite this, the Gamburtsev Subglacial Mountains anomalies differ from the anomalies over Lake Vostok, the central Transantarctic Mountains and the South Pole, implying the presence of multiple distinct Precambrian crustal blocks.

During the Antarctic field seasons 2008/09 and 2009/10, roughly 100,000 line-km of aerogeophysical data were obtained within the International Collaboration for Exploration of the Cryosphere through Aerogeophysical Profiling (ICECAP) project aboard an instrumented long-range Basler DC-3T aircraft (Holt et al., 2010; Young et al., 2010). The multi-national project addresses key IPY 2007/09 themes on frontiers in polar exploration including ICECAP's gravity, magnetic, ice radar observations are providing new insights into the dynamic evolution of the crust and overlying ice sheet of Wilkes Land, East Antarctica.

Geophysical surveys were flown mostly on lines radiating from the Casey Station of the Australian Antarctic Division in Wilkes Land and radial lines emanating from McMurdo Station. The area of first year survey encompassed the Aurora Subglacial Basin and the region near the mouth of the Totten Glacier, one of the largest in Antarctica, as well as the Astrolabe Basin where the thickest ice in Antarctica is located (Young et al., 2010). Flights from the McMurdo station covered the southern part of the Wilkes Subglacial Basin and linked to the IPY AGAP survey at Dome C (Holt et al., 2010).

ICECAP's comprehensive aerogeophysical data provide a first look at the gross lithology of the central Antarctic Plate and aid in interpreting its large scale structural geology, which is a keystone for tectonic reconstructions and other geologic issues. These data will help fill in one of the largest gaps in the ADMAP compilation and can significantly advance our understanding of the dynamic evolution of the earth's largest ice sheet.

In the Prince Charles Mountains (PCM) and surrounding areas, Russian aeromagnetic investigations seek to contribute data on the tectonics of the mobile belts and cratonic fragments, the crustal structure of the Lambert rift system and its development, the tectonic boundaries beneath the ice sheet, and other major aspects of Antarctic geology. Over the past decade, the PMGE projects (RAE 45-56) acquired more than 63,300 line-km of integrated aerogeophysical survey data including magnetic and radar information over the largely ice-covered regions of MacRobertson Land and Princess Elizabeth Land, East Antarctica (Golynsky et al., 2010). The airborne surveys were performed with a standard profile spacing of $5 \mathrm{~km}$ and tie-line spacing of $15-25 \mathrm{~km}$. Taking into account previous PMGE surveys (Golynsky et al., 2006b, 
2006c), of the total aeromagnetic data collected in this region exceeded more than 154,400 line- $\mathrm{km}$. Together with the PCMEGA and AGAP surveys (Damaske and McLean, 2005; Ferraccioli et al., 2009b; Studinger et al., 2009) the PMGE dataset forms the longest transect ever mapped in East Antarctica exceeding $1950 \mathrm{~km}$ in length. Moreover, two reconnaissance lines connect this transect with the PPT project that crosses the Transantarctic Mountains near the South Pole (Studinger et al., 2006), as well as with the CASERTZ and the US/UK surveys in the Amundsen Sea embayment further west (Holt et al., 2006; Sweeney et al., 1999; Vaughan et al., 2006). Thus, these surveys provide a new and uniform window through which tectonic structures and lithologies of the East Antarctic Shield, PalaeozoicCenozoic magmatic arc systems, inherited Early Paleozoic crustal features along the flanks of the West Antarctic Rift System, and other important crustal features can be studied.

\section{New marine magnetic surveys}

Marine magnetic surveys from the 1990s that were not used in the initial ADMAP compilation (Golynsky et al., 2001) were conducted largely by Japanese and American expeditions (e.g. Cande et al., 1995; Joshima et al., 2001; Nogi et al., 2004). These geophysical programs were completed along selected tracks where for the most part magnetic total field, swath bathymetric, seismic (multi-channel and single-channel), and gravity observations were obtained. However, these data mostly come in the form of random tracks, the orientations of which are rarely optimum for investigating the magnetic fabrics of the crust.

The Japanese institutions (i.e., NIPR - National Institute of Polar Research, and GSJ - Geological Survey of Japan) completed several scientific cruises along the East Antarctic margin (e.g. Joshima et al., 2001; Nogi et al., 2004). All data acquired by the GSJ and three campaigns by the NIPR during the Japanese Antarctic Research Expedition (JARE40-42) in the 1999/2001 seasons on board the icebreaker Shirase obtained vector geomagnetic anomaly field data were used to compile a new magnetic anomaly map of the East Antarctic and surrounding areas (Golynsky et al., 2007). During the seven subsequent Antarctic field seasons, roughly 87,000 line-km of shipborne data were obtained by the NIPR (JARE 43-49) that promise to further detail the tectonic evolution of the East Antarctic continental margin (Y. Nogi, pers. communication).

The scientific interests of US researches has been located largely in the Ross Sea sector and along the Pacific margin of the West Antarctica where they collected more than 83,000 line-km of magnetic data during 1992/2007 cruises of the Nathaniel B. Palmer (R/V NBP) research vessel (Cande et al., 1995). These data have determined further details on the early history of spreading of the Bellingshausen plate relative to Pacific, and constrained the original position of the Campbell Plateau relative to the Iselin Bank and Marie Byrd Land crust of West Antarctica (Cande et al., 2000). They identified N-NW magnetic anomalies in the northern Ross Sea which appear to have been formed by Early Tertiary seafloor spreading between East and West Antarctica (Cande and Stock, 2006; Stock and Cande, 2002). Until recently, however, these magnetic data were not available publicly. These data are very important for defining magnetic anomaly patterns of the West Antarctic Pacific margin that continues to be most poorly mapped region of the Southern Ocean. This is especially true for the Amundsen and eastern Ross seas, which exhibit the poorest coverage of any of the marine areas.

Parts of the Scotia, Bellingshausen, Amundsen and Weddell seas were surveyed by BAS ships from 2000 to 2008 for more than 58,000 line-km (T. Deen, pers. communication). The collected profiles tend to meander and because the differing scientific programs of successive cruises have resulted in different profile orientations. This complicates the data processing somewhat relative to processing of aeromagnetic data obtained usually flown in a grid pattern.
Accordingly, the BAS and R/V NBP data from turns frequently need to be rejected and long winding survey tracks split into straight line segments to avoid problems caused by the imperfect compensation of the ships and diurnal variation adjustments.

The Indo-Antarctic continental margin was studied by Australian and Russian researchers with several cruises. These surveys provided new constraints on the break-up processes and igneous activity related to the formation of the passive margin of East Antarctica. The programs of the Russian/Australian Expeditions (RAE 41-56) acquired integrated bathymetric, seismic, gravity and magnetic data of more than 100,000 line-km along the East Antarctic continental margin west of the Maud Rise to George V Coast of Victoria Land (Gandyukhin et al., 2002, 2006; Golynsky et al., 2007; Leitchenkov et al., 2008, 2010; Stagg et al., 2004). These were by far the most wide-ranging geoscience surveys carried out by any program in the most poorly understood part of the world's oceans off of Antarctica. Similar sets of geophysical data were collected by the Norwegian/ Russian (8000 line-km) expeditions during the 2002/04 seasons in the Riiser-Larsen and Cosmonaut seas under a cooperative agreement between the PMGE and the Norwegian Petroleum Directorate (Leitchenkov et al., 2008; Solli et al., 2007).

Marine magnetic data were collected during the 2001/2002 seasons within the Australian Antarctic and Southern Ocean Profiling Project (AASOPP) under the Department of Finance and Administration of Australia to define the outer limits of the continental shelf offshore of the Australian Antarctic Territory (AAT). These efforts covered the full length of the AAT from $40^{\circ} \mathrm{E}$ to $160^{\circ} \mathrm{E}$ with the exception of the French territory of Terre Adélie $\left(\sim 136^{\circ} \mathrm{E}-142^{\circ} \mathrm{E}\right)$ (Gaina et al., 2007; Stagg et al., 2004, 2006). The majority of the survey lines extended from beyond the shelf edge towards the deep ocean basin in water depths of $3000-5000 \mathrm{~m}$ and is spaced at intervals $80-180 \mathrm{~km}$ along the continental margin.

\section{Conclusions}

Since the production of the ADMAP-2001 map, more than 1.5 million line-km of new marine and airborne magnetic survey data, as well as much improved satellite magnetic observations from the Ørsted and CHAMP missions have become available. These new magnetic data together with survey data that were not previously in the public domain can significantly upgrade the ADMAP compilation for crustal studies of the Antarctic. The synthesis of these magnetic data into the next generation ADMAP compilation will enable a better understanding of the geological structure and tectonic history of the Antarctic region. In particular, improved modeling of geodynamic evolution of the Antarctic lithosphere that was a key component in the break-up of Rodinia and Gondwana is possible. Improved perceptions of the nature of transition from the Antarctic continent to its modern oceanic surroundings also can result from the next generation ADMAP compilation for the Antarctic region south of $60^{\circ} \mathrm{S}$. The new magnetic anomaly map of the East Antarctic continental margin compiled recently by Golynsky et al. (this volume) incorporates all available data obtained by the international community since the IGY $1957-58$ to 2009 . This map provides the most complete magnetic anomaly data set compiled for the region to date and can be considered a key element of the new generation ADMAP.

\section{Acknowledgments}

We thank SCAR for supporting the activities of the ADMAP expert group. We are grateful to all members of the ADMAP expert group for their contributions and thank Tara Deen, Karsten Gohl, Yoshifumi Nogi, Daniel Steinhage, Marta Ghidella and Rene Forsberg for providing geodetic coordinates of the recently acquired airborne and marine 
magnetic surveys. We appreciate the constructive suggestions provided by the editor and journal reviewers.

\section{References}

Anderson, E.D., Finn, C.A., Damaske, D., Abraham, J.D., Goldmann, F., Goodge, J.W. Braddock, P., 2006. Aeromagnetic and gravity data over the central Transantarctic Mountains (CTAM), Antarctica: a website for the distribution of data and maps. U.S. Geological Survey Open File Report 2006-1255 http://pubs.usgs.gov/of 2006/1255/ (21 pp.).

Bamber, J.L., Ferraccioli, F., Joughin, I., Shepherd, T., Rippin, D.M., Siegert, M.J., Vaughan, D.G., 2006. East Antarctic ice stream tributary underlain by major sedimentary basin. Geology 34 (1), 33-36. doi:10.1130/G22160.1.

Behrendt, J.C., LeMasurier, W.E., Cooper, A.K., Tessensohn, F., Trehu, A., Damaske, D. 1991. Geophysical studies of the West Antarctic Rift System. Tectonics 10 (6) 1257-1273.

Brancolini, G., Gantar, C., Lodolo, E., Marchetti, A., 1991. Acquisition, processing and preliminary results of the 1988/89 Antarctic geophysical survey. Memorie della Società Geologica Italiana 46, 543-560.

Cande, S.C., Stock, J.M., 2006. Constraints on the timing of extension in the Northern Basin, Ross Sea. In: Fütterer, D.K, et al. (Ed.). Antarctic contributions to Global Earth Science. 9th International Symposium on Antarctic Earth Sciences. SpringerVerlag, Berlin, pp. 317-324

Cande, S.C., Raymond, C.A., Stock, J., Haxby, W.F., 1995. Geophysics of the Pitman Fracture Zone and Pacific-Antarctic plate motions during the Cenozoic. Science 270, 947-953.

Cande, S.C., Stock, J.M., Muller, R.D., Ishihara, T., 2000. Cenozoic motion between East and West Antarctica. Nature 404, 145-150.

Cooper, A.K., Davey, F.J. (Eds.), 1987. The Antarctic Continental Margin: Geology and Geophysics of the Western Ross Sea. Circum-Pacific Council of Energy and Minera Resources, Houston, TX, pp. 27-76.

Damaske, D., 1999. Merging aeromagnetic data collected at different levels the GEOMOD survey. Annali Di Geofisica 42 (2), 153-159.

Damaske, D., McLean, M., 2005. An aerogeophysical survey south of the Prince Charles Mountains, East Antarctica. Terra Antartica 12 (2), 87-98.

Damaske, D., Finn, C.A., Moeller, H.-D., Demosthenous, C., Anderson, E.D., 2002. Aeromagnetic data centered over Skelton Neve, Antarctica: a Web Site for Distribution of Data and Maps (on-line edition). U.S. Geological Survey Open-File-Report $02-452$.

Damaske, D., Ferraccioli, F., Bozzo, E., 2003. Aeromagnetic Anomaly Investigations along the Antarctic Coast between Yule Bay and Mertz Glacier. Terra Antarctica $10,85-96$.

Damaske, D., Läufer, A.L., Goldmann, F., Möller, H.-D., Lisker, F., 2007. Magnetic anomalies north-east of Cape Adare, northern Victoria Land (Antarctica), and their relation to onshore structures. In: Cooper, A.K., Raymond, C.R., et al. (Eds.), Proceeding of the 10th ISAES: USGS Open-File Report 2007-1047, Short Research Paper 016. doi:10.3133/of2007-1047.srp016 (5 pp.).

Damaske, D., Ferraccioli, F., Finn, C., Studinger, M., 2009. Aeromagnetic surveying in remote, unexplored terrain: the Gamburtsev Mountains, East Antarctica. American Geophysical Union, Fall Meeting 2009, abstract \#GP13C-0780.

Ferraccioli, F., Bozzo, E., Capponi, G., 2002. Aeromagnetic and gravity constraints for an early Paleozoic subduction system of Victoria Land, Antarctica. Geophysical Research Letters 29 (10), 1406. doi:10.1029/201GL0141138.

Ferraccioli, F., Damaske, D., Bozzo, E., Talarico, F., 2003. The Matusevich aeromagnetic anomaly over Oates Land, East Antarctica. Terra Antarctica 10, 221-228.

Ferraccioli, F., Jones, P.C., Corr, H., Curtis, M.L., Smith, A.M., Vaughan, A.P.M., Leat, P.T Vaughan, d.g., 2004. Recent airborne geophysics exploration projects of the British Antarctic Survey. Frontiers and Opportunities in Antarctic Geosciences, Certosa d Pontignano, 29-31 July 2004.

Ferraccioli, F., Jones, P.C., Curtis, M.L., Leat, P.T., Riley, T.R., 2005a. Tectonic and magmatic patterns in the Jutulstraumen rift (?) region, East Antarctica, as imaged by highresolution aeromagnetic data. Earth Planets Space 57, 767-780.

Ferraccioli, F., Jones, P.C., Curtis, M.L., Leat, P.T., 2005b. Subglacial imprints of early Gondwana break-up as identified from high resolution aerogeophysical data over western Dronning Maud Land, East Antarctica. Terra Nova 17 (6), 573-579. doi:10.1111/j.1365-3121.2005.00651.x

Ferraccioli, F., Jones, P.C., Vaughan, A.P.M., Leat, P.T., 2006. New aerogeophysical view of the Antarctic Peninsula: more pieces, less puzzle. Geophysical Research Letters 33, L05310. doi:10.1029/2005GL024636.

Ferraccioli, F., Jordan, T.A., Vaughan, d.g., Holt, J., James, M., Corr, H., Blankenship, D.D., Fairhead, J.D., Diehl, T.M., 2007. New aerogeophysical survey targets the extent of the West Antarctic Rift System over Ellsworth Land. In: Cooper, A.K. Raymond, C.R., et al. (Eds.), Antarctica: a Keystone in a Changing World - Online Proceedings of the 10th ISAES X: USGS Open-File Report 2007-1047, Extended Abstract, 113 (4 pp.)

Ferraccioli, F., Armadillo, E., Jordan, T., Bozzo, E., Corr, H., 2009a. Aeromagnetic exploration over the East Antarctic Ice Sheet: a new view of the Wilkes Subglacial Basin. Tectonophysics 478 (1-2), 62-77. doi:10.1016/j.tecto.2009.03.013.

Ferraccioli, F., Bell, R.E., Studinger, M., Damaske, D., Jordan, T.A., Corr, H., Braaten, D.A., Gogineni, P.S., Fahnestock, M., Finn, C., Rose, K., 2009b. New aerogeophysical exploration of the Gamburtsev Province (East Antarctica). American Geophysica Union, Fall Meeting 2009, abstract \#C52A-01.

Ferris, J., Johnson, A., Storey, B., 1998. Form and extent of the Dufek intrusion, Antarctica from newly compiled aeromagnetic data. Earth and Planetary Science Letters 154 185-202.
Ferris, J.K., Vaughan, A.P.M., King, E.C., 2002. A window on West Antarctic crustal boundaries: the junction between the Antarctic Peninsula, the Filchner Block, and Weddell Sea oceanic lithosphere. Tectonophysics 347, 13-23.

Finn, C., Moore, D., Damaske, D., Mackey, T., 1999. Aeromagnetic legacy of early Paleozoic subduction along the Pacific margin of Gondwana. Geology 27, 1087-1090.

Finn, C., Damaske, D., Ferraccioli, F., Studinger, M., Jordan, T.A., Rose, K., Block, A.E., Frearson, N., Bell, R.E., Golynsky, A., 2009. Disclosing Precambrian secrets of the East Antarctic Shield: an aeromagnetic perspective from the international polar year. Fall meeting of American Geophysical Union (AGU), San Francisco, USA, 2009: Eos Trans. AGU, Fall Meet. Suppl. (Abstract C52A-02).

Gaina, C., Müller, R.D., Brown, B., Ishihara, T., Ivanov, S., 2007. Breakup and early seafloor spreading between India and Antarctica. Geophysical Journal International 1-19. doi:10.1111/j.1365-246X.2007.03450.X.

Gandyukhin, V., Gouseva, Y., Kudryavtsev, G., Ivanov, S., Leitchenkov, G., 2002. Crustal structure, seismic stratigraphy and tectonic history of the Cosmonaut Sea sedimentary basin (Antarctica, southern Indian Ocean). Exploration and Protection of Mineral Resources (In Russian) 9, 27-31.

Gandyukhin, V.V., Kuznetsova, L.A., Kuznetsov, A.I., Fedorova, M.A., Ivanov, S.V., Kazankov, A. Yu, 2006. Marine geophysical studies in the Davis Sea, East Antarctica. Russian Earth Science Research in Antarctica 1, 94-100 (St.-Petersburg).

Gaya-Piqué, L.R., Ravat, D., de Santis, A., Torta, J.M., 2006. New model alternatives for improving the representation of the core magnetic field of Antarctica (In Russian). Antarctic Science 18, 101-109.

Gohl, K., Leitchenkov, G.L., Parsiegla, N., Ehlers, B.-M., Kopsch, C., Damaske, D., Guseva, Y.B., Gandyukhin, V.V., 2007a. Crustal types and continent-ocean boundaries between the Kerguelen Plateau and Prydz Bay, East Antarctica. In: Cooper, A.K., Raymond, C.R., et al. (Eds.), Antarctica: a Keystone in a Changing World - Online Proceedings of the 10th ISAES X: USGS Open-File Report 2007-1047, Extended Abstract 038 (4 pp.)

Gohl, K., Teterin, D., Eagles, G., Netzeband, G., Grobys, J.W.G., Parsiegla, N., Schlüter, P., Leinweber, V., Larter, R.D., Uenzelmann-Neben, G., Udintsev, G.B., 2007b. Geophysical survey reveals tectonic structures in the Amundsen Sea embayment, West Antarctica. In: Cooper, A.K., Raymond, C.R., et al. (Eds.), Antarctica: a Keystone in a Changing World - Online Proceedings of the 10th ISAES: USGS Open-File Report 2007-1047, Short Research Paper 047. doi:10.3133/of2007-1047.srp047 (4 pp.).

Golynsky, A., Jacobs, J., 2001. Grenville-Age versus Pan-African Magnetic Anomaly imprints in Western Dronning Maud Land, East Antarctica. Journal of Geology 109, 136-142.

Golynsky, A.V., Grikurov, G.E., Kamenev, E.N., 2000. Geologic significance of regional magnetic anomalies in Coats Land and Western Dronning Maud Land. Polarforshung 67, 91-99.

Golynsky, A., Chiappini, M., Damaske, D., Ferraccioli, F., Ferris, J., Finn, C., Ghidella, M., Ishihara, T., Johnson, A., Kim, H.R., Kovacs, L., LaBrecque, J., Masolov, V., Nogi, Y., Purucker, M., Taylor, P., Torta, M. 2001. ADMAP - Magnetic Anomaly Map of the Antarctic, 1:10 000000 scale map, in: Morris, P., and von Frese, R. (Eds.), BAS (Misc.) 10. British Antarctic Survey, Cambridge.

Golynsky, A.V., Alyavdin, S.V., Masolov, V.N., Tscherinov, A.S., Volnukhin, V.S., 2002. The composite magnetic anomaly map of the East Antarctica. Tectonophysics 347, 109-120.

Golynsky, A., Chiappini, M., Damaske, D., Ferraccioli, F., Finn, C., Ghidella, M., Ishihara, T., Kim, H.R., Kovacs, L., Masolov, V., Morris, P., Nogi, Y., von Frese, R., 2006a. ADMAP - a digital magnetic anomaly map of the Antarctic. In: Fütterer, D.K., Damaske, D., Kleinschmidt, G., Miller, H., Tessensohn, F. (Eds.), Antarctica Contributions to Global Earth Sciences. Springer-Verlag, Berlin Heidelberg New York, pp. 109-116.

Golynsky, A.V., Golynsky, D.A., Masolov, V.N., Volnukhin, V.S., 2006b. Magnetic anomalies of the Grove Mountains region and their geological significance. In: Fütterer, D.K., Damaske, D., Kleinschmidt, G., Miller, H., Tessensohn, F. (Eds.), Antarctica Contributions to Global Earth Sciences. Springer-Verlag, Berlin Heidelberg New York, pp. 95-106.

Golynsky, A.V., Volnukhin, V.S., Golynsky, D.A., Leonov, V.O., Kiselev, A.V., 2006c. Magnetic anomaly field of Mac-Robertson Land and its possible geological origin (airborne geophysical survey during the 49-th Russian Antarctic Expedition). Russian Earth Science Research in Antarctica, Collection of papers, vol. 1. I.S. Gramberg VNIIOkeangeologia, St. Petersburg, pp. 116-126.

Golynsky, A., Blankenship, D., Chiappini, M., Damaske, D., Ferraccioli, F., Finn, C., Golynsky, D., Goncharov, A., Ishihara, T., Ivanov, S., Jokat, W., Kim, H.R., König, M., Masolov, V., Nogi, Y., Sand, M., Studinger, M., von Frese, R., the ADMAP Working Group, 2007. New magnetic anomaly map of East Antarctica and surrounding regions. In: Cooper, A.K., Raymond, C.R., et al. (Eds.), Proceedings of the 10th ISAES: SGS Open-File Report 2007-1047, Short Research Paper 050. doi:10.3133/ of2007.srp050 (4 pp.).

Golynsky, A.V., Golynsky, D.A., Kiselev, A.V., Leonov, V.O., Masolov, V.N., 2010. Russian aeromagnetic data define the width of Proterozoic igneous belt over MacRobertson Land of East Antarctica. Oslo IPY Conference. T2-7 Solid earth geophysical and geochemical processes, PS1.

Goodge, J.W., Finn, C.A., 2010. Glimpses of East Antarctica: aeromagnetic and satellite magnetic view from the central Transantarctic Mountains of East Antarctica. Journal of Geophysical Research 115, B09103. doi:10.1029/2009JB006890.

Golynsky, A.V., Ivanov, S.V., Kazankov, A.Ju., Jokat, W., Masolov, V.N., von Frese, R.R.B. and the ADMAP Working Group, this volume. New continental margin magnetic anomalies of East Antarctica. Tectonophysics (2012).

Hinz, K., Block, M., 1984. Results of geophysical investigations in the Weddell Sea and in the Ross Sea, Antarctica. Proceedings of the 11th World Petroleum Congress, London 1983, vol. 2. Wiley, New York, pp. 79-91. 
Hinz, K., Kristoffersen, Y., 1987. Antarctica, recent advances in the understanding of the continental shelf. Geologisches Jahrbuch E37, 3-54.

Holt, J.W., Blankenship, D.D., Morse, D.L., Young, D.A., Peters, M.E., Kempf, S.D., Richter, T.G., Vaughan, A.P.M., Corr, H., 2006. New boundary conditions for the West Antarctic Ice Sheet: subglacial topography of the Thwaites and Smith Glacier Catchments. Geophysical Research Letters 33. doi:10.1029/2005GL025561 (4 pp.).

Holt, J.W., Blankenship, D.D., Ferraccioli, F., Vaughan, D.G., Young, D.A., Kempf, S.D. Diehl, T.M., 2007. New aeromagnetic results from the Thwaites Glacier catchment, West Antarctica. In: Cooper, A.K., Raymond, C.R., et al. (Eds.), Antarctica: a Keystone in a Changing World - Online Proceedings of the 10th ISAES: USGS Open-File Report 2007-1047, Extended Abstract 153 (3 pp.).

Holt, J.W., Young, D.A., Blankenship, D.D., Greenbaum, J.S., Schroeder, D.M., Richter T.G., Wright, A.P., Siegert, M.J., the ICECAP team, 2010. Bed topography of the Byrd Glacier trunk = from airborne radar soundings of the ICECAP project. Paper presented at SCAR XXXI, Open Science Conference (August 3-6), Buenos Aires, Argentina.

Jokat, W., Boebel, T., König, M., Meyer, U., 2003. Timing and geometry of early Gondwana breakup. Journal of Geophysical Research 108 (B9), 2428.

Jokat, W., Nogi, Y., Leinweber, V., 2010. New aeromagnetic data from the western Enderby Basin and consequences for Antarctic-India break-up. Geophysical Research Letters 37, L21311. doi:10.1029/2010GL045117.

Jones, P., Ferraccioli, F., Corr, H., Smith, A.M., King, E., Vaughan, D., 2003. Aerogeophysical evidence for complex subglacial geology below the Rutford drainage basin, West Antarctica. AGU Fall Meeting, USA, December 2003, abstract \#C31B-0402.

Joshima, M., Ishihara, T., Nakajima, T., Sugiyama, K., Tsuchida, K., Kato, A., Murakami, F., Brown, B., 2001. Preliminary results of the TH99 geological and geophysical survey in the Cooperation Sea and Prydz Bay area. Polar Geoscience, NIPR 14, 244-262.

Kim, H.R., von Frese, R.R.B., Golynsky, A.V., Taylor, P.T., Kim, J.W., 2004. Applications of satellite magnetic observations for estimating near-surface magnetic anomalies. Earth, Planets, and Space 52, 955-966.

Kim, H.R., von Frese, R.R.B., Taylor, P.T., Golynsky, A.V., Gaya-Piqué, L.R., Ferraccioli, F., 2007. Improved magnetic anomalies of the Antarctic lithosphere from satellite and near-surface data. Geophysical Journal International 1-8. doi:10.1111/j.1365246X.2007.03516.x.

Leinweber, V.T., Jokat, W., 2012. The Jurassic history of the Africa-Antarctica corridor new constraints from magnetic data on the conjugate continental margins. Tectonophysics. doi:10.1016/j.tecto.2011.11.008, (23 pp).

Leitchenkov, G., Guseva, J., Gandyukhin, V., Grikurov, G., Kristoffersen, Y., Sand, M., Golynsky, A., Aleshkova, N., 2008. Crustal structure and tectonic provinces of the Riiser-Larsen Sea area (East Antarctica): results of geophysical studies. Marine Geophysical Research. doi:10.1007/s11001-008-9051-z.

Leitchenkov, G.L., Guseva, Ju.B., Gandyukhin, V.V., Gohl, K., Ivanov, S.V., Golynsky, A.V., A.Ju., Kazankov, 2010. Crustal tectonics and depositional history in the Southern Indian Ocean (East Antarctica: Cooperation Sea, Davis Sea, Kerguelen Plateau). In: Leonov, Ju.G. (Ed.), Structure and evolution of the lithosphere, Moscow, Paulsen, 9-38.

Luyendyk, B.P., Wilson, D.S., Siddoway, C.S., 2003. Eastern margin of the Ross Sea rift in western Marie Byrd Land, Antarctica: crustal structure and tectonic development Geochemistry, Geophysics, Geosystems 4 (10), 1090. doi:10.1029/2002GC000462.

Maus, S., Barckhausen, U., Berkenbosch, H., Bournas, N., Brozena, J., Childers, V., Dostaler, F. Fairhead, J.D., Finn, C., von Frese, R.R.B., Gaina, C., Golynsky, S., Kucks, R., Luehr, H., Milligan, P., Mogren, S., Mueller, R.D., Olesen, O., Pilkington, M., Saltus, R., Schreckenberger, B., Thebault, E., Tontini, F., Tontini, C., 2009. EMAG2: A 2-arc min resolution Earth Magnetic Anomaly Grid compiled from satellite, airborne, and marine magnetic measurements. Geochem. Geophys. Geosyst. 10, Q08005. doi:10.1029/2009GC002471 (12pp).

McLean, M.A., Wilson, C.J.L., Boger, S.D., Betts, P.G., Rawling, T.J., Damaske, D., 2009. Basement interpretations from airborne magnetic and gravity data over the Lambert Rift region of East Antarctica. Journal of Geophysical Research 114, B06101. doi:10.1029/2008JB005650 (20 pp.).

Nogi, Y., Nishi, K., Seama, N., Fukuda, Y., 2004. An interpretation of the seafloor spreading history of the West Enderby Basin between initial breakup of Gondwana and anomaly C34. Marine Geophysical Researches 25, 221-231. doi:10.1007/s11001-005-1317-0.

Riedel, S., Jokat, W., 2007. A compilation of new airborne magnetic and gravity data across Dronning Maud Land, Antarctica. In: Cooper, A.K., Raymond, C.R., et al. (Eds.), Antarctica: a Keystone in a Changing World - Online Proceedings of the 10th ISAES: USGS Open-File Report 2007-1047, Extended Abstract 149 (4 pp.).

Rignot, E., Thomas, R.H., Kanagaratnam, P., Casassa, G., Frederick, E., Gogineni, S., Krabill, W., Rivera, A., Russell, R., Sonntag, J., Swift, R., Yungel, J., 2004. Improved estimation of the mass balance of glaciers draining into the Amundsen Sea sector of West Antarctica from the CECS/NASA 2002 campaign. Annals of Glaciology 39, 231-237.
Shepherd, T., Bamber, J.L., Ferraccioli, F., 2006. Subglacial geology in Coats Land, East Antarctica, revealed by airborne magnetics and radar sounding. Earth and Planetary Science Letters 244, 323-335.

Solli, K., Kuvaas, B., Kristoffersen, Y., Leitchenkov, G., Guseva, J., Gandjukhin, V., 2007. Seismic morphology and distribution of inferred glaciomarine deposits along the East Antarctic continental margin, $20^{\circ} \mathrm{E}-60^{\circ} \mathrm{E}$. Marine Geology 237, 207-223.

Stagg, H.M.J., Colwell, J.B., Direen, N.G., O'Brien, P.E., Brown, B.J., Bernardel, G., Borissova, I., Carson, L., Close, D.B., 2004. Geological framework of the continental margin in the region of the Australian Antarctic Territory. Geoscience Australia Record 2004/25. (356 pp.).

Stagg, H.M.J., Colwell, J.B., Borissova, I., Ishihara, T., Bernardel, G., 2006. The Bruce Rise Area, East Antarctica: formation of a continental margin near the Greater IndiaAustralia-Antarctica triple junction. Terra Antartica 13 (1/2), 3-22.

Stock, J.M., Cande, S.C., 2002. Tectonic history of Antarctic seafloor in the AustraliaNew Zealand-South Pacific Sector: implications for Antarctic Continental Tectonics. In: Gamble, J.A., Skinner, D.N.B., Henrys, S. (Eds.), Antarctica at the close of a Millennium: Royal Society of New Zealand Bulletin, 35, pp. 251-259.

Studinger, M., Bell, R.E., Karner, G.D., Tikku, A.A., Holt, J.W., Morse, D.L., Richter, T.G., Kempf, S.D., Peters, M.E., Blankenship, D.D., Sweeney, R.E., Rystrom, V.L., 2003. Ice cover, landscape setting, and geological framework of Lake Vostok, East Antarctica. Earth and Planetary Science Letters 205 (3-4), 195-210. doi:10.1016/S0012-821X (02)01041-5.

Studinger, M., Bell, R.E., Buck, R., Karner, G.D., Blankenship, D.D., 2004. Sub-ice geology inland of the Transantarctic Mountains in light of new aerogeophysical data. Earth and Planetary Science Letters 220, 391-408. doi:10.1016/10.1016/S0012-821X(04) 00066-4.

Studinger, M., Bell, R.E., Fitzgerald, P.G., Buck, W.R., 2006. Crustal architecture of the Transantarctic Mountains between the Scott and Reedy Glacier region and South Pole from aerogeophysical data. Earth and Planetary Science Letters 250, 182-199.

Studinger, M., Bell, R.E., Ferraccioli, F., Damaske, D., Finn, C., Braaten, D.A., Fahnestock M.A., Jordan, T.A., Corr, H., Elieff, S., Robinson, C., Frearson, N., Geue, D., McMinn, M.C., Burton, B., Goldmann, F., Block, A.E., Bates, M., Rose, K., 2009. AGAP: exploring the Gamburtsev Subglacial Mountains with Aerogeophysical Surveys during the IPY. American Geophysical Union, Fall Meeting 2009, abstract \#C53B-08.

Sweeney, R.E., Finn, C.A., Blankenship, D.D., Bell, R.E., Behrendt, J.C., 1999. Central West Antarctica aeromagnetic data: a web site for distribution of data and maps. Open File Report 99-420, U. S. Geological Survey.

Thomas, R., Rignot, E., Casassa, G., Kanagaratnam, P., Acuna, C., Akins, T., Brecher, H. Frederick, E., Gogineni, P., Krabill, W., Manizade, S., Ramamoorthy, H., Rivera, A. Russell, R., Sonntag, J., Swift, R., Yungel, J., 2004. Accelerated sea level rise from West Antarctica. Science 306, 255-258.

Vaughan, D.G., Corr, H., Ferraccioli, F., Frearson, N., O'Hare, A., Mach, D., Holt, J.W., Blankenship, D.D., Morse, D.L., Young, D.A., 2006. New boundary conditions for the West Antarctic Ice Sheet: subglacial topography beneath Pine Island Glacier. Geophysical Research Letters 33, L09501. doi:10.1029/2005GL025588 (4 pp.).

von Frese, R.R.B., Kim, H.R., Taylor, P.T., Asgharzadeh, M.F., 2005. Reliability of CHAMP anomaly continuations. In: Reigber, C., Lühr, H., Schwintzer, P., Wickert, J. (Eds.), Earth Observation with CHAMP Results from Three Years in Orbit. Springer-Verlag, Heidelberg, pp. 287-292.

von Frese, R.R.B., Golynsky, A.V., Kim, H.R., Gaya-Piqué, L., Thébault, E., Chiappini, M. Ghidella, M., Grunow, A., the ADMAP Working Group, 2008. The next generation Antarctic digital magnetic anomaly map. In: Cooper, A.K., Raymond, C.R. (Eds.) Proceedings of the 10th ISAES, USGS Open-File Rept. 2007-1047. doi:10.3133/ of2007.srp163.

Wilson, G., Damaske, D., Möller, H.-D., Tinto, K., Jordan, T., 2007. The geological evolution of southern McMurdo Sound - new evidence from a high-resolution aeromagnetic survey. Geophysical Journal International 170, 93-100. doi:10.1111/j.1365246X.2007.03395.X.

Young, D.A., Blankenship, D.D., Siegert, M.J., van Ommen, T., Wright, A.P., Roberts, J.L., Holt, J.W., Greenbaum, J.S., Frederick, B.C., Schroeder, D.M., Warner, R.C., Young, N.W., the ICECAP team, 2010. Extent, geomorphology and geophysics of the Aurora and Wilkes subglacial basins, East Antarctica: influences on ice sheet architecture. Paper presented at SCAR XXXI, Open Science Conference (August 3-6), Buenos Aires, Argentina.

Zayatz, I., Kavun, M., Traube, V., 1990. The Soviet geophysical research in the Ross Sea in: A.K. Cooper, P.N. Webb (Conveners). International Workshop on Antarctic Offshore Seismic Stratigraphy (ANTOSTRAT), Overview and Extended Abstracts. US Geological Survey Open-File Report 90-309, 283-290. 